\title{
The Role of Community Learning Activity Centers (PKBM) in the Context of Changing the Social Behavior of Street Children
}

\author{
Hikmat \\ UIN Sunan Gunung Djati, Bandung, Indonesia \\ Email: hikmat@uinsgd.ac.id
}

\begin{abstract}
This study aims to determine the role of the Community Learning Activity Center (PKBM) in changing the social behavior of street children. The learning model carried out in this study is about handling, the approach process action, and the form of socialization carried out by the Management and Experts at the Community Learning Activity Center for street children on the streets. It is hoped that with the guidance of street children in PKBM, it is expected that changes in the attitudes and social behavior of street children can be seen. The method used by the author in this study is qualitative. The data collection techniques used in this research are interview, observation, and literature study, including documentation. The results showed that the role of the Learning Activity Center in helping to change the social behavior of street children was perfect. However, here and there, there were still some shortcomings such as lack of discipline, self-confidence, and lack of care for the surrounding environment. The empowerment carried out by PKBM includes the development of life skills, academic activities, and religious activities.
\end{abstract}

Keywords: Education, Community Learning Activity Center (PKBM), Social Behavior, Street Children.

\section{A. INTRODUCTION}

Street children have the same rights as other children; they need to get broad opportunities to grow and develop optimally both physically, mentally, and socially (Sofyan \& Tenripadang, 2017). The Republic of Indonesia Law Number 35 of 2014 concerning amendments to Law Number 23 of 2002 concerning child protection Article 1 paragraph (2), states that. "Child protection is all activities to guarantee and protect children and their rights so that they can live, grow and develop, and participate optimally, following human dignity, and receive protection from violence and discrimination".

Street children such as scavengers, buskers, beggars, and so on are more susceptible to delinquency cases. Based on data from the Ministry of Social Affairs (Kemensos) published on the website www.Republika.co.id, there were at least 8,937 cases of criminal delinquency that happened to street children during 2017. sex, to alcohol. There were 2,117 cases of obscenity, 1,244 cases of theft, 1,115 cases of molestation or fights, 1,108 cases of rape, 989 cases of neglect, 326 cases of traffic accidents, 281 cases of physical and mental violence victims, then neglected children under five (ABT) victims. 243 criminal acts, 195 narcotics cases, 94 murder cases, 56 cases of kidnapping victims, and 52 cases of gambling (Yuliato, 2017). 
Seeing the many cases that occur in street children is an indication that there has been a moral crisis in the younger generation, especially children. Bad morals arise due to weak inculcation of attitudes from an early age. Education, both formal and religious, is essential for children's attitudes and character growth and development. Education can be the first step to fortify children from bad attitudes and behaviors in society, such as delinquency, obscenity, theft, drinking, and drugs. , 2018). The formation of attitudes in preschool or early age is a period that is very influential on physical growth, intellectual development, social, emotional, moral, religion, personality, language, and creativity. The family and community environments strongly influence the development of attitudes and behavior.

Education policies for street children in Indonesia are currently fully managed by each local government to decentralize education. This is expressed by Dwiningrum (2011) that decentralization of education will facilitate access to implementing education policies, especially for street children. Suci (2017) explains that the selfconcept of street children tends to be negative because many drops out of school or do not get the appropriate education. The street child felt disappointed and embarrassed and felt that everyone thought he was stupid. On the other hand, the street child thinks that he is nothing, and he also feels inferior compared to other children. So the education policy for street children is considered necessary because street children need to get decent jobs.

Educational efforts for street children have been carried out by many official institutions, in this case, the government and social institutions that care about the problems of street children. Likewise, in this case, the Ministry of Education and Culture, along with the Ministry of Social Affairs, has made various efforts to tackle the problem of street children by involving various related agencies (Aminatun, 2013). One of the educational policy programs for street children is PKBM. Nurkholis (2014) said that PKBM provides a positive picture of street children's education programs. PKBM, in conducting coaching, does not only want to achieve or develop student knowledge but also the attitudes and character of the students who are there through Life Skill activities which consist of skills programs and child attitude development. Street children have a free and wild background in life; they carry out activities without knowing the time, words that tend to be impolite, lack honesty, cannot be regulated, have rude behavior, or care less about the environment (Syahrul \& Wardana, 2017).

So that the development of children's social attitudes is not wrong, it is necessary to have the right attitude coaching program, so that street children have a good mentality. Through PKBM, activities such as Life Skills and a religious approach become a forum for directing street children to have good social attitudes to become helpful adults. In its development, it is also necessary to have activities that can change the mood of street children to get out of street life and be oriented towards education, both formal and non-formal. The importance of changing mindsets and behavior is the main thing so that children with working backgrounds in the street want to be fostered to follow their education (Dahlan, 2014). 
Judging from these various descriptions, research on the Role of Community Learning Activity Centers (PKBM) in changing the Social Behavior of Street Children needs to be done. It is hoped that this research can be a reference for the government and local governments in dealing with the problems of street children, especially in the field of education. And for other researchers, it can be used as a reference in developing efforts to empower and change the social behavior of street children.

\section{B. METHOD}

The research method used in compiling this research uses descriptive qualitative methods, namely methods that produce descriptive data. The data was obtained from manuscripts, interviews, field notes, recording devices, and other official documents (Creswell, 2014). As for the sampling or data sources of this research with purposive techniques, namely sampling or data sources intentionally or determined by the researcher. The validity of the data is done by triangulating sources, methods, and theories. The research data were analyzed using qualitative techniques moving in a circle between data collection, data organizing, reading/memorizing, description, classification, interpretation, and presentation/visualization.

\section{RESULT AND DISCUSSION}

Street children first appeared at the end of 1997 due to the drought and the prolonged economic crisis. The results of the author's research show that the problem of street children is dominantly caused by poverty or family incompetence $(98 \%)$, in addition to family incompatibility (33\%) and family violence (23\%). Street children are estimated to be at least 50 thousand children, an estimate based on data from homeless people and beggars (Irwanto et al., 1998). In this case, the problem of street children is an iceberg phenomenon, small on the surface, but the difficulties inside are much broader and complex. If 50 thousand were detected in 1998, then it is possible that with the interest of homegrown children who are vulnerable to becoming street children to take to the streets, plus the increasing social problems that arise, this number doubled in 2010. nowadays, "street children" and "street youths" have started to increase. One day it is possible that "street old people" will appear. A further consequence of this condition, if it is not immediately handled thoroughly with the right approach, is the loss of generation (lost of age) as the successor to the relay of struggle and quality leadership of the nation (Anasiru, 2011).

The social problems of street children are also related to the inability of children to obtain their rights, as regulated by the Convention on the Rights of the Child. Also, due to the lack of accessibility of children, due to various limitations of existing facilities and infrastructure. Both at home and in the surrounding environment, to play and develop according to their growth period. Related to these conditions, the problem of street children is already a crucial problem that must be addressed to the roots. Because the situation is only handled on the surface, then these problems will reappear every time and cause other problems that are even more complex. Such as 
the emergence of street adults, crime, thuggery, exploitation of energy, sexual exploitation, behavioral deviations, etc. (Saputra, 2018).

The results of the author's research, street children also have a "stigma" associated with their behavior which is considered to deviate from the general norms that exist in the surrounding community. However, they also have potential which, if touched with the right approach, can become social capital or social capital for street children in facing various dynamics of their lives in the future, as well as being able to be used to improve their quality of life so that they can continue to "survive" life. On the streets, gradually getting out of the way, no longer dependent on life on the streets. This is in line with what was stated by Fukuyama (2000) that humans have unique abilities to collaborate and create social capital; they do this in ways that can protect their interests as individuals.

The stigma given by the community to street children is caused in their lives on the streets, both individually and in groups; they try to develop a sub-culture with norms and values that are different from those that apply in general. On the one hand, it may be positive because it can protect their existence, but on the other hand, it is negative. This is because the growing norms and values deviate from the generally accepted standards and values. Besides that, normative social behavior also appears, such as indifference and excessive suspicion towards people outside the group, unruly, wild, reactive, sensitive, accessible and tends to only hang out/interact with the group, ignorant, etc. (Wulandari et al., 2016).

Behavior is a series of activities that can change if the current needs increase in strength to become the highest motive (Hersey \& Blanchard, 1969). The five main concepts of reinforcement that can assist in behavior change efforts are positive reinforcement of the new desired behavior as soon as possible, negative reinforcement, punishment, extinction, and schedule reinforcement. This is related to behavior modification theory which focuses on observed behavior and uses external goals or rewards to modify and shape behavior towards the desired achievement (Hersey \& Blanchard, 1969).

Concerning changes in behavior and its relation to one's condition, Hurlock (1979) states firmly that "a person's attitude is not only determined by the person concerned but is also determined by environmental factors, meaning the attitude of the people around him towards himself. concerned". From this explanation, it is clear that behavior change can only occur if two factors, namely the person concerned and the people around him, are both in a situation that wants the change to occur.

Moenir (1988) suggests three categories of behavior change in a person, namely in terms of 1) impact, seen from the positive and negative effects, permanent or temporary, and the development is fast, regular, or slow. If changes occur quickly, it can cause difficulties for yourself because the surrounding environment doubts the meaning of the change. After all, it may be only temporary (false), 2) nature, involves the process because it involves one's beliefs, beliefs, and personality factors, and 3) time, change takes time, it's fast, regular, or slow. However, it can be taken as a general 
and common standard that the adjustment process of a person in an environment lasts between 3-12 months.

From the conditions described above, the critical thing to pay attention to is that street children can change their behavior through modified activities by involving their desire and awareness to want to learn and study the changes that occur in their lives independently so that they are no longer maladjusted and informative. Through the process of independent learning or self-learning, children are also accustomed to overcoming obstacles that occur in their efforts to adapt and change their behavior. So it is hoped that new behaviors are internalized when they come out of their lives on the streets.

Social attitude is the process of individuals training themselves for sensitivities in acting in a community or group of people and the environment. According to the cognitive dissonance theory proposed by Festinger, attitude change can be carried out through an attitude component consisting of cognitive (understanding, beliefs, and views), namely the development and evolution of street children in processing the information, knowledge, and opinions they have, leaving the old mindset that they have and have a strong view of changing fate and developing understanding, affective (feelings in the form of, sympathy, empathy, and antipathy) developments that arise due to the responses they receive, street children can get used to and like positive things and their increased sensitivity to themselves, the environment and society, and conative (tendency to behave) in this study the behavioral tendencies measured were following educational standards, namely the 2013 curriculum, namely on social attitudes.

Researchers measure attitude change using social attitudes, including honesty, discipline, responsibility, tolerance, cooperation, courtesy and courtesy, and selfconfidence. In the cognitive dissonance theory proposed by Festinger, attitude change occurs through intervention on individuals through individual cognition or thought; if the individual has received a stimulus through his cognition or thought, it will impact the practical or personal feeling towards a particular person stimulus or object. It will influence individuals to tend to perform certain behaviors called conative.

The results of the study show that from several aspects of attitude change in the Cognitive Aspect, their view of the future changed from only looking at making money on the street as an essential activity for them, becoming aware that going to school and having knowledge are much more important things, going to school and having skills. Can release them from the harsh marginal life. The Affective Aspect shows that apart from empathy, they feel sad and sorry to see their peers who have not been able to receive an education. They also have a feeling of sympathy to help a friend in trouble.

The Conative Aspects in this study tend to be social attitudes showing street children students experience changes in attitudes to become more honest individuals, public perceptions of street children who tend to judge street children from an opposing point of view, making street children challenging to gain trust from the community. Building trust can be done with an attitude of responsibility that is always 
done well and kept, and never runs away from the difficulties and problems that are being faced, an attitude of tolerance shows street children have the principle of free life, so they never see a difference as a disturbing obstacle. Them, because street children tend to be indifferent to social strata and the views of others, the cooperative attitude of street children can be seen in the following actions that reflect cooperation, among others: being actively involved in community service cleaning classes/schools, performing tasks according to the agreement, helping others without expecting rewards, working actively with groups, not prioritizing personal interests, and looking for ways or solutions together, street children students all informants can identify attitudes that show politeness and courtesy, and in the observations of the researchers the nine informants were children the streets have a good record in PKBM.

Based on information obtained from nine informants, four informants revealed that they used to be shy individuals. Still, they have been able to adapt and increase their self-confidence for now. In comparison, the other three informants of street children said that they never found it difficult to get along, while for two informants of street children, others said they are not yet sociable.

The existence of activities in PKBM is the process of changing the social behavior of street children, fulfilling and increasing the self-skills of street children, making street children enthusiastic about changing their social behavior, which they should not have. The addition of knowledge also helps develop the creativity of street children because most street children still harbor what the street children's skills are. Awards for street children can make street children happy and willing to change well, especially in the handling area of all the facilities that street children do not have when on the streets. Still, they have been able to fulfill the facilities they need at the handling site, education which was previously constrained because of the lack of funds. Still, at the handling place, they are guaranteed education and supervision is emphasized, so that street children no longer live on the streets, they should not roam the streets because of their age who still need management.

Changes in the Social Attitudes of Street Children in PKBM indicate that the values of social attitudes of street children have seen quite good chances. However, a small part of the informants of street children students still has not experienced significant changes. When viewed from the component of attitude change and aspects of social attitudes, which include the cognitive component, the visible changes are their views and beliefs which consider school to be important from the previous standpoint that only orienting working on the road is an essential and mandatory thing for them to do. The visible changes are the increase in knowledge and skills, which before they went to school reading, writing, and counting activities were things they had not mastered, they also won awards in various art performances, their skills were also honed, previously only looking for money in the sector working in the way, they change the way they make money by trading or by helping teach at PKBM, the affective component, children's care has been seen both, a sense of empathy and sympathy has begun to grow in their personality, it's just that there is still a feeling of antipathy to the traumatic events they have experienced, while fork The conative 
component, which is the attitude component in this study, uses a tendency to behave and behave from social attitude indicators. It can be explained that the honest attitude of children is good, marked by their deterrent to dishonest behaviors they experience.

Some of the responsibilities of children are good enough that they know how to be responsible and what their responsibilities are now. Children's tolerance is quite good because they have a feeling of the same fate and the tendency of street children who think freely and have high solidarity, Gotong royong or children's cooperation is quite good, they often form a joint activity and complete tasks as well as competitions in groups, Polite. Children's manners have undergone a significant change because they have a good record at school and look courteous daily. Some children have confidence in themselves, some have experienced relatively good changes. It's just that a small number still need further guidance because they still lack confidence.

\section{CONCLUSION}

The problem of street children arises due to the inability of children to obtain their rights and the lack of accessibility due to the limitations of existing facilities and infrastructure. One of the efforts to foster street children is through education, where the local government fully manages the policy as a form of education decentralization. Education policy to change the social behavior of street children is through the Community Learning Activity Center (PKBM). The role of PKBM in changing the social behavior of street children can be measured using social attitudes, including honesty, discipline, responsibility, tolerance, cooperation, courtesy and courtesy, and self-confidence. The results showed that the existence of PKBM was able to change the social behavior of street children through self-skill training, academic and religious education. The presence of PKBM can change the social behavior of street children where they have a sense of responsibility, cooperation, tolerance, and good manners.

\section{REFERENCES}

1. Aminatun, S. (2013). Pemberdayaan Anak Jalanan Melalui Sanggar Karya Anak Bangsa. Jurnal Penelitian Kesejahteraan Sosial, 12(4), 367-378.

2. Anasiru, R. (2011). Implementasi Model-Model Kebijakan Penanggulangan Anak Jalanan di Kota Makassar. Sosio Konsepsia: Jurnal Penelitian dan Pengembangan Kesejahteraan Sosial, 16(2), 175-186.

3. Creswell, J. W. (2014). Penelitian Kualitatif dan Desain Riset: Memilih di Antara Lima Pendekatan. Yogyakarta: Pustaka Pelajar.

4. Dahlan, H. (2014). Gerakan Nyata Dalam Penanganan Anak Jalanan. Media Informasi Penelitian Kesejahteraan Sosial, 38(2).

5. Dwiningrum, S. I. A. (2011). Desentralisasi dan Partisipasi Masyarakat dalam Pendidikan. Yogyakarta: Pustaka Pelajar.

6. Fukuyama, F. (2000). Social Capital and Civil Society. SSRN.

7. Hersey, P., \& Blanchard, K. H. (1969). Life cycle theory of leadership. Training $\mathcal{E}$ Development Journal. 
8. Hurlock, E. B. (1979). Personality Development. Tata Mc. Graw Hill Publishing Company Ltd. New Delhi

9. Irnawati, C. (2018). Hipnoterapi Untuk Peningkatan Perilaku Personal Hygiene Anak Jalanan Di Ppap Seroja Kodya Surakarta (Doctoral dissertation, Universitas Mercu Buana Yogyakarta).

10. Khoiri, Q. (2018). Model Dan Pendekatan Pendidikan Agama Islam Bagi Remaja Di Kelurahan Tengah Padang Kota Bengkulu. Tadrib, 4(2), 301-318.

11. Law No. 23 of 2002 on Child Protection

12. Moenir. (1988). Kepemimpinan Kerja Peranan, Teknik dan Keberhasilannya. Jakarta: Bina Aksara.

13. Nurkholis, D. (2014). Program kesejahteraan sosial anak untuk anak rentan jalanan di Yayasan Domore. S1 Thesis. Not Published. Universitas Negeri Yogyakarta.

14. Saputra, M. (2018). Pemberdayaan Warga Negara dan Kewirausahaan Sosial: Pemutusan Mata Rantai Anak Jalanan. Jurnal Ilmiah Pendidikan Pancasila dan Kewarganegaraan, 3(2), 144-148.

15. Sofyan, A. M., \& Tenripadang, A. (2017). Ketentuan Hukum Perlindungan Hak Anak Jalanan Bidang Pendidikan. DIKTUM: Jurnal Syariah dan Hukum, 15(2), 229246.

16. Suci, D. T. (2017). Konsep diri anak jalanan. SCHOULID: Indonesian Journal of School Counseling, 2(2), 14.

17. Syahrul, S., \& Wardana, A. (2017). Analisis Kebijakan Pendidikan Untuk Anak Jalanan di Kota Yogyakarta. Harmoni Sosial: Jurnal Pendidikan IPS, 4(2), 117-130.

18. Wihyanti, R. (2019). Peran Mahasiswa Dalam Pemenuhan Hak Anak Jalanan Melalui Rumah Singgah. Sosio Informa, 5(1).

19. Wulandari, S. P., Mudjahidin, M., \& Hapsery, A. (2016). Keterampilan Interpersonal Sebagai Pendidikan Anak Jalanan di Rumah Pintar Matahari Surabaya. In PRISMA, Prosiding Seminar Nasional Matematika (pp. 443-448).

20. Yulianto, A. (2017). Ini Kasus-kasus yang dialami Anak Jalanan . Jakarta . Retrieved from Republika: https://www.republika.co.id/berita/nas ional/umum/18/01/15/p2lhcc396. 